\title{
EFEK DIURETIK EKSTRAK AKAR PANDAN WANGI (Pandanus Amaryllifolius Roxb) PADA MENCIT JANTAN
} (Mus musculus L)

\author{
Karmilah $^{1}$, Hasnawati ${ }^{2}$ \\ Akademi Farmasi Bina Husada Kendari ${ }^{1}$ \\ Universitas Halu Oleo, Program Studi Farmasi ${ }^{2}$ \\ E-mail : karmilahakfar@gmail.com
}

\begin{abstract}
ABSTRAK
Diuretik merupakan obat yang dapat menambah kecepatan pembetukan urin. Tumbuhan Akar pandan wangi merupakan salah satu tanaman yang mengandung beberapa senyawa bioaktif salah satunya senyawa alkaloid. Alkaloid dalam tubuh berperan dalam meningkatkan volume urin (diuresis), yang bekerja langsung pada tubulus dengan cara meningkatkan ekskresi $\mathrm{Na}^{+}$dan $\mathrm{Cl}$. Tujuan penelitian adalah untuk mengetahui efek diuretik ekstrak akar pandan wangi dan mengetahui dosis yang memiliki efek optimal dalam memberikan efek diuretik pada mencit jantan. Ekstrak di peroleh menggunakan pelarut etenol 70\% dengan metode maserasi. Jenis penelitian adalah eksperimen yang terdiri atas lima perlakuan dengan tiga kali pengulangan. Sediaan ekstrak akar pandan wangi diberikan secara oral pada mencit dengan dosis $250 \mathrm{mg} / \mathrm{kg} \mathrm{BB}, 500 \mathrm{mg} / \mathrm{kg} \mathrm{BB}$ dan $750 \mathrm{mg} / \mathrm{kg}$ BB dengan interval waktu 15, 30, 45, 60, 90, dan 120 menit dengan Furosemid sebagai kontrol positif dan $\mathrm{Na}$ CMC sebagai kontol negatif. Hasil penelitian menunjukkan bahwa ketiga perlakuan dari sampel dapat memberikan efek diuretik yaitu sediaan ekstrak $250 \mathrm{mg} / \mathrm{kg}$ BB efek diuretik terjadi dengan jumlah frekuensi $15 \mathrm{kali}$, ekstrak $500 \mathrm{mg} / \mathrm{kg}$ BB dengan jumlah frekuensi $20 \mathrm{kali}$, ekstrak $750 \mathrm{mg} / \mathrm{kg} \mathrm{BB}$ sebanyak 16 kali, sedangkan suspensi furosemid terjadi dengan frekuensi 26 kali dan Na CMC terjadi 10 kali frekuensi. Hasil dari uji ANOVA dan uji LSD menunjukan ekstrak akar pandan wangi (Pandanus Amaryllifolius Roxb), pada konsentrasi $500 \mathrm{mg} / \mathrm{kg}$ BB efektif memberikan efek diuretik.
\end{abstract}

\section{Kata Kunci : Diuretik, akar pandan wangi, Mencit}

\section{ABSTRACT}

Diuretics are drugs that are able to increase the speed of formation of urine.. The root of fragrant pandan plant is a plant that contains several bioactive compounds one alkaloid compounds. Alkaloids in the body plays a role in increasing the volume of urine (diuresis). Alkaloids work directly on the tubules by increasing the excretion of $\mathrm{Na}^{+}$and $\mathrm{Cl}^{-}$. The purpose of this study was to determine the effect of root extract fragrant pandan diuretic and dose that has an optimal effect in giving a diuretic effect mice. The extract obtained using ethanol $70 \%$ by maceration method. This type of research is an experiment consisting of 
five treatments with three repetitions. Research conducted by providing preparation root extract fragrant pandan orally in mice at a dose of $250 \mathrm{mg} / \mathrm{kg}$, $500 \mathrm{mg} / \mathrm{kg}$ and $750 \mathrm{mg} / \mathrm{kg}$ with intervals of 15, 30, 45, 60, 90, and 120 minutes with furosemide as a positive control and $\mathrm{Na} \mathrm{cmc}$ as negative dick. The results showed that all three treatments of samples may provide a diuretic effect is dosage extract $250 \mathrm{mg} / \mathrm{kg}$ body weight diuretic effect occurs with the number of frequencies 15 times, extract $500 \mathrm{mg} / \mathrm{kg}$ body weight by the number of frequency of 20 times, extract $750 \mathrm{mg} / \mathrm{kg}$ body weight 16 times, whereas furosemide suspensions occur with a frequency of 26 times and Na CMC occur with a frequency of 10 times. Results of ANOVA and LSD showed root extract fragrant pandan at a concentration of $500 \mathrm{mg} / \mathrm{kgBB}$ effectife to give diuretic effect.

\section{Keywords : Diuretic, root extract fragrant pandan, Mice}

\section{PENDAHULUAN}

Dalam ilmu kesehatan, ada beberapa penyakit yang proses pencegahanmaupun penyembuhannya memerlukan proses pengeluaran urin yang lebih dari biasanya. Urin adalah bagian penting dari pembuangan tubuh karena mengadung zat yang beredar dalam tubuh termasuk bakteri, ragi, kelebihan protein dan gula, maka diperlukan zat-zat atau obat yang mampu meningkatkan proses pengeluaran urin yang disebut diuretik.

Diuretik adalah obat yang dapat menambah kecepatan pembetukan urin. Istilah diuresis mempunyai dua pengertian, pertama menunjukkan adanya penambahan volume urin yang diproduksi dan yang kedua menjukkan jumlah pengeluaran (kehilangan) zat-zat terlarut dalam air (Nafrialdi, 2012).

Fungsi utama diuretik adalah untuk memobilisasi cairan edema, yang berarti mengubah keseimbangan cairan sedemikian rupa sehingga volume cairan ekstrasel kembali menjadi normal (Nafrialdi, 2012). Sampai saat ini obat-obat diuretik sintetik memiliki kekurangan atau efek samping jika dikonsumsi dalam jangka panjang diantaranya menyebabkan gangguan keseimbangan cairan dan elektrolit seperti hipokalemia, hiperglikemia, hiperurikemia, dan hiperlipidemia (Tjay dan Raharja, 2002).

Saat ini telah banyak masyarakat beralih keobat-obatan yang berasal dari alam. Selain efek terapeutiknya dipercaya, dan mudah diperoleh juga 
tidak memiliki efek samping. Salah satu tanaman yang berpotensi sebagai diuretik adalah akar pandan wangi (Pandanus amaryllifolius Roxb), akar pandan wangi mengandung senyawa kimia alkaloida, saponin, flavonoida, tanin, polifenol dan zat warna (Dalimartha, 1999).

Menurut Nessa (2013), senyawa alkaloid dalam tubuh yang bekerja langsung pada tubulus dengan cara meningkatkan ekskresi $\mathrm{Na}^{+}$dan $\mathrm{cl}^{-}$. Dengan meningkatnya ekskresi $\mathrm{Na}^{+}$ akan dapat meningkatkan ekskresi air dan menyebabkan volume urin bertambah. Berdasarkan hal tersebut, akar pandan wangi yang mengandung senyawa alkaloid berpotensi sebagai obat diuretik.

Berdasarkan penelitian (Mario A. Tan, 2014) Akar pandan laut (pandanus tectorius) uji efek diuretik terhadap ekstrak akar pandan dengan dosis $500 \mathrm{mg} / \mathrm{kg}$ BB - 1000 $\mathrm{mg} / \mathrm{kg} \mathrm{BB}$, dan efek yang efektif diberikan pada dosis $500 \mathrm{mg} / \mathrm{kg} \mathrm{BB}$. Berdasarkan uraian di atas, maka dilakukan penelitian tentang, Uji Efek Diuretik Ekstrak Akar Pandan Wangi (Pandanus amaryllifolius Roxb) Terhadap Mencit Jantan (Mus musculus L).

\section{METODE PENELITIAN}

\section{Jenis Penelitian}

Jenis penelitian yang digunakan adalah penelitian eksperimental yaitu penelitian yang dilakukan dengan mengadakan manipulasi terhadap objek penelitian serta kontrol.

\section{Alat dan Bahan}

\section{Alat}

Alat yang digunakan adalah Batang pengadukGelas kimia $100 \mathrm{~mL}$ (pyrex) Gelas ukur 100 mL (Pyrex), Hot plate, Kain flannel, Lumpang dan Alu, Rotary evaporator, Lakban hitam, Spoit 1 cc, Spoit oral, Timbangan Digital, Topl.

\section{Bahan}

Bahan yang digunakan adalah Etanol 70\%, Aquadest, Ekstrak akar pandan wangi, Furosemid tablet 40 $\mathrm{mg}, \mathrm{Na} . \mathrm{CMC} 0.5 \% \mathrm{~b} / \mathrm{v}$

\section{Pembuatan ekstrak akar pandan wangi (pandanus amaryllifolius roxb)}

Simplisia di ekstraksi dengan metode maserasi, kemudian ekstrak cair di pekatkan dengan rotavapor, lalu di 
buat konsentari $250 \mathrm{mg} / \mathrm{kg}$ BB 500 $\mathrm{mg} / \mathrm{kg}$ BB dan $750 \mathrm{mg} / \mathrm{kg}$ BB.

\section{Perlakuan Hewan Uji}

Hewan coba sebanyak 15 ekor yang sudah diadaptasikan selama 1 minggu dibagi dalam 5 kelompok, masing-masing terdiri atas 3 perlakuan dan 2 kontrol. Tiap-tiap mencit diberi sediaan sesuai kelompok perlakuan melalui oral dengan menggunakan spoit oral yaitu : Hewan uji dipuasakan selama 3 jam namun tetap diberi minum, kemudian diberi perlakuan:

1) Kelompok I : diberi suspensi ekstrak akar pandan wangi dosi $250 \mathrm{mg} / \mathrm{kg}$ BB sesuai volume pemberian

2) Kelompok II : diberi suspensi ekstrak akar pandan wangi dosis
$500 \mathrm{mg} / \mathrm{kg}$ BB sesuai volume pemberian

3) Kelompok III : diberi suspensi ekstrak akar pandan wangi dosis $50 \mathrm{mg} / \mathrm{kg}$ BB sesuai volume pemberian

4) Kelompok IV (kontrol positif) :diberi suspensi furosemid 40 $\mathrm{mg} / \mathrm{kg} \quad \mathrm{BB}$ sesuai volume pemberian

5) Kelompok V (kontrol negatif) :diberi suspensi NA CMC 0,5 sesuai volume pemberian

6) Dilakukan pengamatan frekuensi diuresis masing-masing mencit dengan interval waktu $15,30,45$, 60, 90 dan 120 menit, dan dicatat semua hasil perlakuan. 


\section{HASIL DAN PEMBAHASAN}

\section{Frekuensi Diuretik pada Hewan Uji Mencit}

Tabel 1. Rata-rata Frekuensi Diuretik Pada Hewan Uji Mencit

\begin{tabular}{cccccc}
\hline Replikasi & \multicolumn{5}{c}{ Rata-rata Frekuensi Diuretik } \\
\cline { 2 - 6 } $\mathbf{1}$ & $250 \mathrm{mg} / \mathrm{kg} \mathrm{BB}$ & $500 \mathrm{mg} / \mathrm{kg} \mathrm{BB}$ & $750 \mathrm{mg} / \mathrm{kg} \mathrm{BB}$ & Furosemid $40 \mathrm{mg}$ & $\mathrm{Na} \mathrm{cmc} 0,5 \%$ \\
$\mathbf{2}$ & 1,0 & 0,83 & 0,5 & 1,6 & 0,5 \\
$\mathbf{3}$ & 0,5 & 1,3 & 1,0 & 1,0 & 0,5 \\
Rata-rata & 1,0 & 1.16 & 1,16 & 1,6 & 0,6 \\
\hline
\end{tabular}

Berdasarkan Tabel 1. Rata-rata

ekstrak akar pandan wangi dengan dosis $250 \mathrm{mg} / \mathrm{kg} \mathrm{BB}$ dengan rata-rata $2 \mathrm{kali}, 500 \mathrm{mg} / \mathrm{kg}$ BB dengan ratarata $3 \mathrm{kali}$, dan $750 \mathrm{mg} / \mathrm{kg}$ BB dengan rata-rata 2 kali, ketiga dosis perlakuan memberikan frekuensi diuretik. Sedangkan pada pembuatan kontrol positif suspensi furosemid, terjadi dengan frekuensi 26 kali dengan ratarata 4 kali, efek ini masih lebih tinggi dibandingkan ekstrak dosis 500 $\mathrm{mg} / \mathrm{kg} \mathrm{BB}$.

Hal ini karena furosemid merupakan obat diuretik kuat dan bertitik kerja dilengkungan Henle bagian menaik yang efektif pada keadaan udema diotak dan paru-paru yang akut. Masa kerjanya peroral dalam 0,5-1 jam (Djamhuri, 1990), sedangkan pada kontrol negatif $(\mathrm{Na}$ CMC) terjadi dengan frekuensi 10 kali dengan rata-rata 1 kali, hal ini karena $\mathrm{Na} \mathrm{CMC}$ Tidak mengandung senyawa yang bersifat sebagai efek diuretik.

Diuretik adalah obat yang dapat menambah kecepatan pembetukan urin. Istilah diuresis mempunyai dua pengertian, pertama menunjukkan adanya penambahan volume urin yang diproduksi dan yang kedua menjukkan jumlah pengeluaran (kehilangan) zat-zat terlarut dalam air (Nafrialdi, 2012). Fungsi utama diuretik adalah untuk memobilisasi cairan edema, yang berarti mengubah keseimbangan cairan sedemikian rupa sehingga volume cairan ekstrasel kembali menjadi normal (Nafrialdi, 2012).

Akar pandan wangi memiliki kandungan kimia alkaloid, saponin, flavonoid, tanin, polifenol, dan zat warna. Alkaloid dalam tubuh bekerja langsung pada tubulus dengan cara meningkatkan ekskresi $\mathrm{Na}^{+}$dan $\mathrm{Cl}$. Dengan meningkatnya ekskresi $\mathrm{Na}^{+}$ 
juga akan meningkatkan ekskresi air dan menyebabkan volume urin bertambah.

Hasil dari efek diuretik yang diperoleh dianalisis statistik dengan menggunakan analisis varians untuk mengetahui adanyan pengaruh terhadap pemberian ekstrak akar pandan wangi menggunakan analisis uji anova. Hasil analisis data secara statistik dengan menggunakan Rancangan Acak Lengkap (RAL) pada taraf kepercayaan $5 \%(0,05)$ diperoleh $\mathrm{F}$ hitung $(5,16)>\mathrm{F}$ tabel $(3,48)$, yang menunjukkan $\mathrm{F}$ hitung lebih besar dari $\mathrm{F}$ tabel yang berarti Ho (Hipotesis) ditolak atau tidak terdapat perbedaan terhadap perlakuan dan $\mathrm{Ha}$ (Hipotesis alternatif) diterima yang berarti terdapat perlakuan.

Dari hasil uji beda nyata terkecil (BNT) didapatkan $\mathrm{t}$ hitung $(0,066)<(2.145) \mathrm{t}$ tabel. Nilai $\mathrm{t}$ hitung inilah yang menjadi pembeda rata-rata tiga sediaan, bila rata-rata tiga sediaan lebih besar dari nilai BNT/LSD, maka dinyatakan berbeda signifikan. Setelah diketahui nilai BNT/LSD pada uji beda nyata terkecil, maka dicari lagi beda mean antar perlakuan ekstrak akar pandan wangi $250 \mathrm{mg} / \mathrm{kg} \mathrm{BB}, 500 \mathrm{mg} / \mathrm{kg} \mathrm{BB}$, dan $750 \mathrm{mg} / \mathrm{kg}$ BB untuk mengetahui sediaan mana yang lebih efektif dalam memberikan efek diuretik. Berdasarkan tabel ketiga ekstrak signifikan terhadap furosemid secara diuretik antara ekstrak $250 \mathrm{mg} / \mathrm{kg} \mathrm{BB}$, $500 \mathrm{mg} / \mathrm{kg} \mathrm{BB}$, dan $750 \mathrm{mg} / \mathrm{kg} \mathrm{BB}$ tidak signifikan. Sehingga berdasarkan hasil tersebut.

Ekstrak akar pandan wangi dengan dosis $250 \mathrm{mg} / \mathrm{kg} \mathrm{BB}, 500$ $\mathrm{mg} / \mathrm{kg}$ BB dan $750 \mathrm{mg} / \mathrm{kg}$ BB dapat memberikan efek diuretik, namun efek optimalnya adalah ekstrak 500 $\mathrm{mg} / \mathrm{kg}$ BB. Hal ini pat di katakan bahwa ekstrak akar pandan wangi 500 $\mathrm{mg} / \mathrm{kg}$ BB efektif dalam memberikan frekuensi diuretik yang dapat dilihat pada tabel Mean yang terdapat dalam lampiran, di katakan efektif karena dengan dosis dibawa $750 \mathrm{mg} / \mathrm{kg}$ BB sudah optimal memberikan frekuensi diuretik. Sedangkan $750 \mathrm{mg} / \mathrm{kg}$ BB tidak dikatakan efektif karena konsetrasi dosis di bawah $500 \mathrm{mg} / \mathrm{kg}$ BB memiliki efek yang rendah selain itu, semakin tinggi dosis, maka semakin besar kemungkinan adanya efek samping. 


\section{KESIMPULAN}

Dari hasil penelitian yang telah dilakukan dapat di simpulkan sebagai berikut :

1. Ekstrak akar pandan wangi dengan dosis $250 \mathrm{mg} / \mathrm{kg} \mathrm{BB}, 500 \mathrm{mg} / \mathrm{kg}$ $\mathrm{BB}, 750 \mathrm{mg} / \mathrm{kg}$ dapat memberikan efek diuretik terhadap hewan coba mencit.

2. Dosis yang efektif dari ekstrak akar pandan wangi dalam memberikan efek diuretik adalah dosis $500 \mathrm{mg} / \mathrm{kg} \mathrm{BB}$.

\section{DAFTAR PUSTAKA}

Dalimartha, dr. Setiawan. 1999. Atlas Tumbuhan Obat Indonesia Jilid $V$. Pustaka Bunda : Jakarta.

Nafrialdi, Gunawan, dan Gan Sulistia. (2012). Farmakologi dan Terapi. Departemen Farmakologi dan Terapeutik FKUI. Jakarta: Balai penerbit FKUI.

Nessa. 2013. Efek Diuretik dan Daya Larut Batu Ginjal dari Ekstrak Etanol Rambut Jagung (Zea mays L.). Fakultas Farmasi, Universitas Andalas. Padang.

Tjay, H. T., dan Rahardja, K., 2002. Obat-Obat Penting (Khasiat, Penggunaan, dan Efek-Efek Samping), Edisi V 372-381 Ditjen PCM RI, Jakarta. 